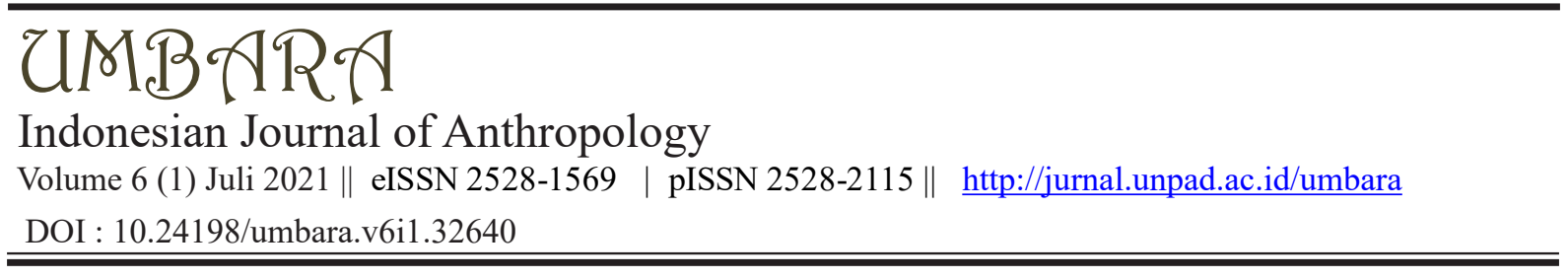

\title{
Model Edukasi Kerelawanan di Sekolah Relawan
}

\author{
Ahmad M. Syarif \\ Departemen Antropologi, Fakultas Ilmu Sosial dan Ilmu Politik, Universitas Indonesia \\ ahmad.maulana03@ui.ac.id
}

\begin{abstract}
This study describes Sekolah Relawan, a Non-Governmental Organization (NGO), whose activities focus on voluntarism education. This study explains the patterns and systems designed by the organization to educate the volunteers in order to achieve their competencies and characters. The educational model of this organization being analyzed using the concept of organizational culture; while paying attention to the basic assumptions of the founder, the values being internalized, and the artifacts being built in the everyday life of the volunteers. This study applied qualitative method, and the data collection techniques include interviews, participant observations and secondary data study. This study suggests that Sekolah Relawan as an NGO builds its sustainability of its educational system through ideas, knowledge, human resources, and funding. Voluntary education by the Sekolah Relawan delivered in stages, starting from education for beginners to experienced volunteers. This model of staged education has affected volunteer's loyalty and program development, and organizational sustainability of the organization.
\end{abstract}

Keywords: organizational culture, volunteer, voluntary education, Non-Government Organization (NGO), Sekolah Relawan

\begin{abstract}
Abstrak
Studi ini mengenai Sekolah Relawan sebagai Lembaga Swadaya Masyarakat (LSM) yang kegiatannya berfokus pada edukasi kerelawanan. Tujuan studi ini menjelaskan pola dan sistem yang dibangun oleh Sekolah Relawan untuk mengedukasi para relawan agar memiliki kompetensi dan karakter yang dibutuhkan. Pada studi ini, model edukasi Sekolah Relawan dianalisis dengan perspektif budaya organisasi; dengan mempertimbangkan asumsi dasar pendiri, nilai-nilai yang ingin diinternalisasi, dan artefak yang dibangun dalam keseharian. Studi ini dilakukan dengan metode kualitatif, dan teknik pengumpulan data dilakukan melalui wawancara, partisipasi observasi serta studi data sekunder. Temuan studi ini menunjukkan bahwa Sekolah Relawan sebagai sebuah LSM, membentuk kompetensi dan karakter para relawan dengan cara membangun aspek keberlanjutan dalam aktivitas edukasinya dari mulai ide, pengetahuan, sumber daya manusia, dan pendanaan. Edukasi kerelawanan dibuat oleh Sekolah Relawan secara berjenjang bagi kalangan relawan pemula hingga relawan yang sudah sangat berpengalaman dengan aktivitas atau mengelola relawan. Model edukasi ini berpengaruh terhadap loyalitas relawan, pengembangan program, dan juga
\end{abstract}


keberlanjutan organisasi.

Kata kunci: budaya organisasi, relawan, edukasi kerelawanan, Lembaga Swadaya Masyarakat (LSM), Sekolah Relawan

\section{Pendahuluan}

Relawan menurut International Labour Organization (ILO) atau Organisasi Buruh Internasional adalah siapapun yang berada pada usia produktif dalam periode yang relatif singkat bekerja tanpa upah, tanpa keharusan menghasilkan produksi atau jasa, dan bukan untuk kepen- tingan pribadi atau keluarganya (International Labour Office, 2011). Relawan sejatinya mendedikasikan dirinya pada suatu kegiatan atau hal tertentu berdasarkan kecintaannya pada kegiatan itu. Kecintaan itu sulit didefinisikan secara tekstual karena bagi para relawan hal itu memiliki konteksnya masing-masing. Setiap relawan memiliki kecintaan pada kegiatan atau hal yang berbeda. Misal, ada yang memiliki kecintaan pada keluarga, lingkungan sekitar, agama, negara, dan sebagainya. Memiliki kecintaan terhadap sesuatu, termasuk pada diri sendiri, menjadi landasan seseorang bertindak untuk berbagi, mengamati apa yang terjadi dengan empati dan mengolahnya untuk dapat menyajikan hal yang bisa dilakukan dirinya "menjadi relawan" sebagai bentuk aktualisasi diri (Syarif, 2018).

Relawan bukan sebatas kata yang tercantum dalam kaos. Bukan sebagai kata yang menjadikan diri seseorang tidak bernilai. Namun, lebih dari itu. Kerelawanan pada dasarnya adalah bagian dari hidup setiap manusia yang tertanam di dalam hati. Hal ini tampak dalam bentuk bantuan dari orang yang saling tidak mengenal tetapi bersedia mendonasikan uang dalam nominal yang banyak, atau pada fenomena orang yang rela meninggalkan keluarga untuk sebuah aktivitas yang berbayar demi rasa kepuasan dalam bingkai kemanusiaan. Transformasi sosial pun sulit hadir tanpa kerja kerelawanan yang terkadang dinilai tidak berharga karena sering tidak ternilai secara finasial dalam konteks ekonomi. Namun, kerelawanan ini memiliki makna dan tentu dunia tidak lengkap tanpa kontribusi para relawan. Aktivitas kerelawanan seperti menjadi guru di pedalaman, tukang sampah di perkotaan, bahkan ibu rumah tangga yang membesarkan anak, juga kental akan dedikasi tetapi sering kali dianggap kurang bernilai (Graeber, 2018).

Umumnya perilaku menolong dilakukan secara spontan ketika ada individu atau komunitas mengalami kesulitan seperti salah satunya ketika terjadi bencana alam (Utomo dan Minza, 2016). Fenomena kerelawanan menjadi hal yang lazim di seluruh dunia, termasuk di Indonesia. Bidang ini telah memiliki sejarah panjang di Indonesia berikut dengan jejaknya. Keberhasilan penanganan bencana besar seperti tsunami di Aceh ada 2004 merupakan salah satu jejaknya. Pada 2018, Indonesia merupakan negara paling dermawan se-dunia versi CAF World Giving Index Report 2018. Beberapa poin yang menjadi indikator dalam penilaian kedermawan tersebut di antaranya, aksi membantu orang asing, donasi yang terkumpul, dan partisipasi menjadi relawan. Posisi Indonesia dalam hal kedermawanan ini di atas Australia (posisi kedua) dan Selandia Baru (posisi ketiga). Setiap tahun, Indonesia selalu masuk dalam urutan tiga besar. Indeks perilaku kedermawan warga Indonesia sering menjadi rujukan bagi banyak kalangan dan tentu saja menjadi sebuah prestasi.

Pasca peristiwa tsunami di Aceh, mulai banyak bermunculan Lembaga Swadaya Masyarakat (LSM) atau Non-Government Organization $(N G O)$ di Indonesia. Salah satunya adalah lembaga sosial Sekolah Relawan yang didirikan oleh seorang rescuer Indonesia bernama Bayu Gawtama. Pendirian organisasi itu, menjadi

\footnotetext{
${ }^{1}$ Charities Aid Foundation (CAF) adalah salah satu lembaga internasional yang membuat survey terkait indeks negara dermawan di dunia.
} 
momentum penting perkembangan pesat kerelawanan di Indonesia.

Nama Sekolah Relawan terinspirasi dari bapak pendidikan Indonesia yang pernah mengatakan bahwa semua tempat adalah sekolah dan semua orang yang kita temui di muka bumi ini adalah guru. Bagi orang awam, sebuah sekolah seringkali dibayangkan sebagai sebuah bangunan sekolah dengan murid, guru, jenjang belajar. Namun, Sekolah Relawan tidak demikian walaupun pada dasarnya Sekolah Relawan memang merupakan ruang belajar bagi para relawan.

Niat baik untuk membantu sesama tidaklah cukup menjadi modal bagi relawan. Begitu pula pergi ke lapangan tanpa memiliki pengetahuan yang baik berpotensi memiliki dampak yang berbahaya, bagi diri relawan maupun orang yang ingin dibantu. Hal ini dikatakan oleh Faas dan Barrios (2015) bahwa pemahaman tentang situasi dan budaya lokal diperlukan oleh para relawan dalam upaya mereka menangani bencana dan mendampingi korban bencana. Tanpa pengetahuan dan pemahaman akan aspek tersebut serta bantuan orang lokal program kerelawanan hanya dapat dijustifikasi di atas kertas, tetapi tidak akan masuk akal dalam konteks lapangan (Maldonado, 2016).

Memaknai aktivitas kerelawanan merupakan tujuan pendirian Sekolah Relawan yang beralamat di Jl. Sawi No. 139, Beji - Kota Depok. Lembaga ini berdiri pada 13 Januari 2013 dengan visi "Relawan Sebagai Pemimpin Bangsa". Saat ini Sekolah Relawan telah berstatus sebagai organisasi nirlaba.

Sekolah Relawan merupakan lembaga sosial kemanusiaan yang berfokus pada edukasi kerelawanan dan pemberdayaan masyarakat sebagai wujud aksi nyata. Lembaga ini memberikan edukasi sekaligus aksi kerelawanan yang akan dibahas lebih dalam pada tulisan ini.

Aksi yang dilakukan oleh Sekolah Relawan diwadahi dalam berbagai tim yang bergerak di bidang program sosial kemanusiaan, termasuk kebencanaan dan program pengembangan masyarakat. Divisi yang menggawangi program sosial kemanusiaan bernama Social Disaster and Rescue atau akrab disebut SDR. Divisi pengembangan masyarakat bernama Indonesian Community Development atau akrab disebut ICD. Pembagian tim ini menggambarkan aktivitas organisasi yang sifatnya emergency-charitable dengan program atau aktivitas yang berkelanjutan.

Organisasi ini beranggotakan para anak muda sebagai pengelola harian lembaga dan sebagian besar berdomisili tinggal di kawasan Jabodetabek. Kisaran umur pengelola antara 22-30 tahun, hanya beberapa orang yang berusia di atas 30 tahun. Usia para pengelola berpengaruh terhadap jangkauan mereka pada calon relawan. Rata-rata relawan yang direkrut tak jauh usianya dengan para pengelola. Pada umumnya, relawan di lembaga ini terafiliasi dengan komunitas lokal di wilayah masing-masing yang tersebar di beberapa daerah di luar Jabodetabek. Afiliasi ini memudahkan lembaga untuk dapat menjangkau aktivitas di beberapa daerah.

Jejaring Sekolah Relawan dengan organisasi komunitas di berbagai wilayah menjadi modal sosial penting. Jejaring dan modal sosial ini ditangani secara khusus oleh sebuah divisi yang bernama Volunteer and Communiy Network (VCN). Tim ini tidak hanya mengolah data, tetapi juga membangun kolaborasi untuk saling mendukung aktivitas kerelawanan yang dilakukan sebagai wadah informasi, serta ruang belajar bersama akan keberagaman relawan dari berbagai suku dan agama. Modal sosial yang dihimpun dari kedekatan jejaring ini bisa mendapatkan keuntungan ekonomi dan juga manfaat sosial (Fathy, 2019).

Sekolah Relawan memberikan beragam edukasi untuk para relawan demi memperkuat aksi di lapangan. Di lembaga ini, para relawan diberi beragam pelatihan, acara rutin, dan juga pendidikan akademi dengan manajemen pembelajaran yang terstruktur. Edukasi dilakukan secara offline maupun online. Kemajuan teknologi memberikan sumbangsih penting bagi lembaga ini untuk memberikan edukasi secara online dalam rangka menjangkau relawan di berbagai daerah. Di sisi lain, kondi- 
si pandemi Covid-19 juga memaksa aktivitas lembaga beradaptasi dengan teknologi digital. Adaptasi itu mendorong adanya inovasi edukasi, seperti edukasi berbasis aplikasi ataupun online course yang telah dimulai sejak saat ini. Hal tersebut juga sebagai bahan adaptasi lembaga dari ancaman era digitalisasi.

Di luar kegiatan edukasi tersebut, Sekolah Relawan juga mendorong tim internal dan para relawan mereka untuk meningkatkan literasi dengan budaya membaca dan menulis sehingga mereka memiliki pengetahuan yang mumpuni. Beberapa buku bacaan baik secara konseptual maupun cerita lapangan berhasil dimulai dan diterbitkan oleh para relawan Sekolah Relawan.

Lalu, bagaimana model edukasi kerelawanan dikelola agar tumbuh berkembang seiring dengan budaya organisasi yang dibangun? Penelitian sebelumnya mengenai relawan sudah cukup banyak, meliputi definisi relawan, motivasi relawan, pelayanan relawan, balasan yang efektif bagi relawan, hingga retensi aksi kerelawanan (Haski-Leventhal dan Bargal, 2008). Studi ini juga akan memberikan gambaran tentang edukasi kerelawanan yang menjadi bagian penting dan bermanfaat bagi peningkatan kapasitas relawan baik untuk $N G O$, pemerintah, atau siapapun yang mengelola relawan dalam aktivitas sosial dengan menampilkan kasus Sekolah Relawan.

\section{Kajian Pustaka}

Ed Schein dan Peter Schein menulis Organizational Culture and Leadership (2017). Mereka menggambarkan lahir dan tumbuhnya budaya organisasi. Mereka menunjukkan dengan detil, peta perkembangan sebuah organisasi. Mereka menunjukkan beberapa poin yang dapat dilihat dan yang tidak terlihat untuk mengaitkan perkembangan organisasi dengan tujuan yang hendak dibangun. Beberapa poin tersebut yaitu berupa tiga jenjang analisa struktur budaya organisasi menurut Schein, di antaranya: 1) artefak, 2) nilai dan 3) kepercayaan yang dimiliki.
Pada studi ini, model edukasi kerelawanan di Sekolah Relawan dalam pengembangannya dibedah menggunakan tiga jenjang analisis struktur budaya artefak, nilai, dan kepercayaan. Ketiga poin tersebut mengkaji ide, gagasan, dan tujuan pendiri dari lembaga edukasi kerelawanan atau bahkan ideologi yang menjadi pendorong kuat lahir dan tumbuhnya organisasi. Selain itu, pada studi ini juga akan ditambahkan aspek asumsi dasar yang menjadi latar belakang pendiri sebagai pisau analisa keempat.

Peningkatan kapasitas relawan diperlukan sebagai upaya memahami tingkah laku dan hubungan sosial ketika memberikan bantuan. Skidmore (1983: 268-276) menjelaskan ada tiga aspek utama yang perlu ditingkatkan, yakni pengetahuan, keterampilan, dan sikap profesional. Beberapa bentuk metode edukasi yang bisa digunakan beragam melalui perkuliahan, bermain peran, program pengembangan diri, kerja kelompok, permainan pelatihan, fasilitas perpustakaan, melanjutkan pendidikan, dan pertukaran.

Sekolah Relawan merupakan Non-Government Organization (NGO) atau Lembaga Swadaya Masyarakat (LSM) yang memiliki sistem dan kebutuhan operasional dalam pengelolaan lembaga untuk dapat mencapai tujuannya. Tulisan Fisher berjudul Doing Good? The Politics and Anti Politics of NGO Practices menjelaskan bahwa $N G O$ atau lembaga non-pemerintah ini tidak selalu homogen, bahkan pembentukannya tidak melulu dari aktor di luar negara; dan funding juga menjadi salah satu poin penting dalam $N G O$ (Fisher, 1997). Walaupun $N G O$ terpisah dari negara secara formal, tetapi NGO mungkin terbentuk dari donor, pemerintah, atau pun akar rumput. Beberapa nomenklatur secara konseptual ada yang menyebut donor-organized NGO's or DONGO's atau lembaga dari donor, ada pula yang mendapat dukungan dari pemerintah yang disebut GONGO's.

Bagaimana salah satu lembaga swadaya dilahirkan? Didukung oleh pihak mana untuk kebutuhan operasional aktivitas programnya? Beberapa pertanyaan ini menjadi penting un- 
tuk dilihat, karena setiap lembaga tidak selalu lahir murni dari bukan aktor negara atau perusahaan dan tumbuh dominan dari donasi publik. Justru bisa jadi sebaliknya.

Edukasi kerelawanan sebuah lembaga tentu memiliki kebutuhan operasional, terlebih jika edukasi yang dilakukan bukan hanya di lokasi organisasi tersebut tumbuh secara geografis. Jejaring komunitas dan relawan di daerah yang ada perlu dirawat dan dikembangkan untuk meningkatkan kapasitas serta loyalitas. Hal ini karena jejaring komunitas dan relawan daerah merupakan bagian yang sangat berharga dalam sebuah organisasi untuk bekerja sama. Fasilitas untuk berbagi ilmu yang diberikan oleh lembaga juga memberikan dampak keterikatan antar jejaring untuk saling memberi. Memberi, menerima dan kembali memberi. Hal ini bukan hanya kepada aspek ekonomi antar manusia, tetapi relasi antara manusia dengan alam, Tuhan dan juga kebudayaan sehingga menciptakan prestasi yang bersifat total seperti penjelasan Mauss dalam karyanya The Gift (1954). Beberapa pemberian baik berupa pelatihan, acara atau beasiswa pendidikan dari lembaga oleh relawan atau komunitas, secara sosial tentu memiliki ikatan atas ide dan praktik lembaga yang menciptakan loyalitas secara tidak langsung dan secara tidak sadar dinikmati oleh para aktor-aktor relawan atau komunitas yang tergabung.

\section{Metode}

Studi ini dilakukan dengan metode kualitatif. Melalui metode ini, peneliti menggambarkan lebih dalam aspek penting yang ingin dikaji terkait pola dan alur model edukasi kerelawanan dalam peningkatan kapasitas relawan. Data untuk studi ini dikumpulkan melalui wawancara, observasi, Focus Group Discussion (FGD) dan beberapa sumber data tertulis yang dimiliki lembaga Sekolah Relawan.

Wawancara dilakukan secara informal pada para pendiri lembaga, dengan tujuan mengetahui ide dan gagasan edukasi kerelawanan yang dibangun secara historis hingga perkembangannya saat ini. Wawancara juga dilakukan dengan beberapa pengelola serta relawan yang aktif mengikuti rangkaian kegiatan edukasi sebagai pencarian data feedback yang dirasakan dari serangkaian program tersebut.

Observasi dilakukan dengan mengikuti aktivitas keseharian yang berlangsung, baik edukasi maupun aksi serta beberapa kali terlibat dalam program edukasi kerelawanan baik secara offline maupun online. Partisipasi observasi juga dilakukan karena peneliti pernah terlibat aktif selama lebih dari dua tahun (Februari 2017 - Desember 2019) sebagai pengelola internal lembaga atau yayasan, khususnya dalam program pengembangan masyarakat.

Beberapa sumber data sekunder yang digunakan dalam studi ini diperoleh di laman sekolahrelawan.com dan sekolahrelawan.org serta beberapa dokumen lain milik organisasi ini. Dokumen yang diizinkan untuk dapat diakses sebagai bahan informasi antara lain company profile, modul pelatihan, galeri dokumentasi kegiatan, road map, serta silabus beberapa kelas pembelajaran.

Studi ini berlangsung selama lima bulan sejak Juli hingga November 2020. Data dikumpulkan dari delapan orang informan yang direkomendasikan oleh lembaga maupun sepengalaman peneliti sewaktu terlibat aktif sebagai pengelola internal Sekolah Relawan. Kategori informan terdiri dari pendiri, pengelola event, trainer dan juga beberapa relawan yang pernah ikut aktif sebagai peserta pelatihan atau kegiatan edukasi.

\section{Hasil dan Pembahasan}

Pada bagian ini akan dijelaskan penggambaran tentang analisa budaya organisasi melalui nilai, artefak, kepercayaan, dan asumsi dasar yang terus disosialisasikan oleh Sekolah Relawan. Artefak merupakan sesuatu yang bisa kita lihat sebagai perwujudan gagasan dan tindakan yang dalam konteks ini bisa berupa program dan atau produk edukasi kerelawanan. Selanjutnya, pengelolaan serta pengembangan program tersebut sesuai dengan ide dasar pendiri dalam sebuah organisasi.

\section{Nilai Kerelawanan dalam Model Edukasi Sekolah Relawan}

Konten edukasi kerelawanan yang dilakukan 
oleh Sekolah Relawan berfokus kepada isu tentang sosial kemanusiaan, kebencanaan dan pengembangan masyarakat. Fokus dari isuisu ini memiliki kesamaan baik dalam rangka edukasi maupun aksi lembaga. Hal ini memudahkan rangkaian pembelajaran mulai dari tahap teoritik hingga praktik. Para relawan yang tergabung berkesempatan untuk belajar dan beraksi sehingga diharapkan terus mengaplikasikan ilmu mereka secara praktikal dan belajar kembali sebagai bentuk pengembangan diri.

Secara kelembagaan, Sekolah Relawan tidak hanya fokus pada agenda edukasi kerelawanan, tetapi juga pada artefak berupa program-program aksi kerelawanan. Melihat dari sejarah dan pengalaman, Sekolah Relawan mendorong para relawan di Indonesia untuk meningkatkan kompetensi dan karakter. Hal ini dilakukan dengan mencoba mengedukasi relawan yang tergabung di dalamnya dan bersinergi dengan lembaga atau instansi lainnya untuk dapat merangkul lebih banyak relawan yang terlatih.

Edukasi dilakukan secara offline maupun online. Pada umumnya sejak Sekolah Relawan berdiri hingga sekarang, program dilakukan dengan cara offline. Namun, perkembangan teknologi serta kasus pandemi Covid-19 mendorong Sekolah Relawan untuk beradaptasi. Adaptasi yang dilakukan membuahkan inovasi untuk pengembangan program edukasi, khususnya dalam efisiensi menjangkau relawan di berbagai daerah. Sekolah Relawan juga melakukan edukasi via platform online untuk dapat tetap berkegiatan dan mengikuti kebiasaan masyarakat industri masa kini. Selain itu, Sekolah Relawan juga sedang dalam proses merencanakan agenda edukasi berbasis online course terkait materi kerelawanan. Hal ini berdampak baik untuk banyak pihak yang bersinergi dan menjadi partner kegiatan lembaga di masa depan.

Berdasarkan data tertulis di road map Sekolah Relawan dan penjelasan model edukasi yang dibuat oleh pendiri, nilai-nilai kerelawanan dirumuskan dalam 6 konsep bertemakan "Good", di antaranya Good Organization, Good System, Good Education and Training, Good Program, Good Experience, dan Good Supervision.

Pertama, Good Organization adalah sebuah model yang digunakan untuk mengembangkan pengelolaan lembaga edukasi. Model ini meliputi pemimpin, tim, manajemen, finansial, jejaring, dan legalitas. Agenda pada pendekatan ini bertujuan untuk menciptakan sebuah tatanan yang profesional dan juga membangun kepercayaan publik. Oleh sebab itu, kegiatan yang dilakukan erat dengan pengembangan diri dan tim serta aktivitas yang sangat administratif seperti legalitas dalam penggalangan, kegiatan atau program, sertifikasi trainer, audit keuangan dan seterusnya. Kegiatan ini merupakan arena perwujudan nilai untuk meningkatkan produktifitas lembaga dalam banyak aspek (Graeber, 2018).

Kedua, Good System dirancang untuk menciptakan standar tertentu bagi tata cara kerja lembaga. Aspek Good System mencakup sistem inventaris, sistem administrasi, sistem keuangan, Standard Operating Procedure (SOP) program dan juga Key Performance Indicator (KPI) bagi masing-masing bidang maupun perorangan. Agenda terkait pembenahan sistem ini menjadi agenda penting, khususnya bagi leader team dari Sekolah Relawan. Mereka adalah tim di lembaga yang sering kali memberikan arahan dan nasihat untuk mengikuti aturan lembaga agar berjalan sesuai dengan apa yang telah menjadi perencanaan lembaga. Sosialisasi maupun internalisasi kepada tim membutuhkan waktu dan usaha yang cukup banyak mengingat sejarah lembaga ini berawal dari komunitas yang sebelumnya sangat kental menganut asas kekeluargaan dan kebersamaan sehingga tidak terlalu sistematis. Beberapa penyesuaian dan perbedaan pendapat pun sering terjadi. Namun, semua kembali berjalan normal karena semua tim baik dari para pimpinan hingga anggota tergabung menganggapnya hal yang wajar dalam dinamika proses belajar.

Ketiga, Good Education and Training merupakan pendekatan yang sangat erat kaitan- 
nya dengan pengembangan produk-produk edukasi lembaga. Di dalam aktivitas turunan ini, pendiri mengharapkan pengelolaan edukasi memiliki konsistensi dan dapat menjangkau lebih banyak relawan di beragam daerah. Model ketiga ini berlanjut dan berkesinambungan dengan model keempat yaitu Good Program. Apabila pendekatan ketiga berfokus pada pengembangan rangkaian edukasi, di model selanjutnya justru pendiri mengarahkan untuk memberikan uji coba atau praktik kepada para relawan sebagai bahan aktualisasi diri. Para relawan dapat belajar langsung mengenai manajemen kerelawanan, dan tentu dimulai dengan program-program yang sederhana. Berlaku prinsip saling membersamai dalam memudahkan dan saling menggiatkan kemauan.

Kelima, Good Experience adalah sebuah model lanjutan untuk dapat merefleksikan diri. Para relawan diharapkan mendapatkan ruang untuk berkembang dengan memiliki pengalaman sehingga lembaga juga memiliki masukan dari mereka yang berkegiatan sebagai bahan pengembangan. Relawan berkesempatan untuk mengikuti program yang diminati, seperti isu kebencanaan, sosial dan atau pengembangan masyarakat. Mereka memiliki mentor yang telah berpengalaman di bidangnya untuk bertanya apabila ada hal yang membingungkan atau hal yang belum dapat dipahami.

Model keenam adalah Good Supervision yang bertujuan agar para relawan dapat berpikir kritis dan saling berdiskusi untuk transformasi sosial. Tidak hanya aktif belajar dan beraksi, mereka juga diharapkan bisa berbagi keilmuan baru di dunia kerelawanan sehingga khazanah ilmu kerelawanan dapat terus diperbaharui seiring dengan perkembangan jaman.

Model "Good" Sekolah Relawan ini bertujuan untuk meningkatkan kompetensi dan juga karakter relawan. Kompetensi yang dimiliki relawan akan membantu mereka memahami secara partisipasi aktif dan secara holistik situasi di masyarakat. Kompetensi ini akan melampaui pemahaman mereka pada sekadar kelebihan dan kekurangan, pro dan kontra sehingga rela- wan tumbuh lebih digdaya tidak seperti robot yang hanya melakukan apa yang diperintah (Banerjea, 2011).

Model edukasi kerelawanan ini adalah model yang dikembangkan oleh Sekolah Relawan sejak pertama berdiri hingga saat ini. Model ini terus berkembang mengingat kesadaran para pendiri akan adanya limitasi dalam model yang coba dibuat dan dikembangkan.

\section{Artefak dalam Program Edukasi Kerela- wanan Sekolah Relawan}

Sejauh ini, Sekolah Relawan telah membuat cukup banyak artefak berupa program edukasi kerelawanan. Di dalam studi ini, program tersebut dikategorisasi berdasarkan bentuk, di antaranya kegiatan atau acara (event), pelatihan (training) dan akademi (academy). Kategori bentuk ini memiliki perbedaan terkait ruang, waktu dan juga bobot yang berbeda. Di sisi lain, bentuk ini juga dapat menjadi rantai pembelajaran dari mulai belajar tingkat dasar hingga tinggi versi Sekolah Relawan. Pada bagian ini akan memuat bagaimana setiap bentuk tersebut bekerja bersama produknya dan kemungkinan perkembangannya ke depan.

Kegiatan/acara/event adalah bentuk program yang sifatnya selesai dalam satu hari. Kegiatan ini tidak memakan durasi waktu yang lama. Satu kegiatan biasanya terdiri dari satu hingga tiga sesi dengan durasi satu hingga dua jam per sesi. Beberapa produk edukasi yang termasuk dalam kategori kegiatan/acara/ event antara lain Orientasi Relawan (OR) dan Forum Sharing. Program yang dibuat bertujuan untuk memberikan pengetahuan dan juga pengantar dalam menumbuhkan minat orang menjadi relawan terlatih. Pada umumnya program tersebut tidak berbayar. Hal ini merupakan teknik pemasaran yang sengaja dibuat dan dipahami sebagai rangkaian promosi atau ajakan bagi orang untuk mau belajar lebih lanjut bersama. Di dalam kegiatan tersebut, mereka dikenalkan materi-materi kerelawanan dasar atau sebagian saja; dan materi tentang aktivitas lembaga dan bentuk pelatihan apabila mereka tertarik lebih lanjut dalam bidang tertentu. Program OR tidak hanya dilakukan 
di basecamp Sekolah Relawan dan untuk relawan di Jabodetabek, tetapi juga melakukan road show ke beberapa daerah non-Jabodetabek sebagai perluasan jejaring modal sosial.

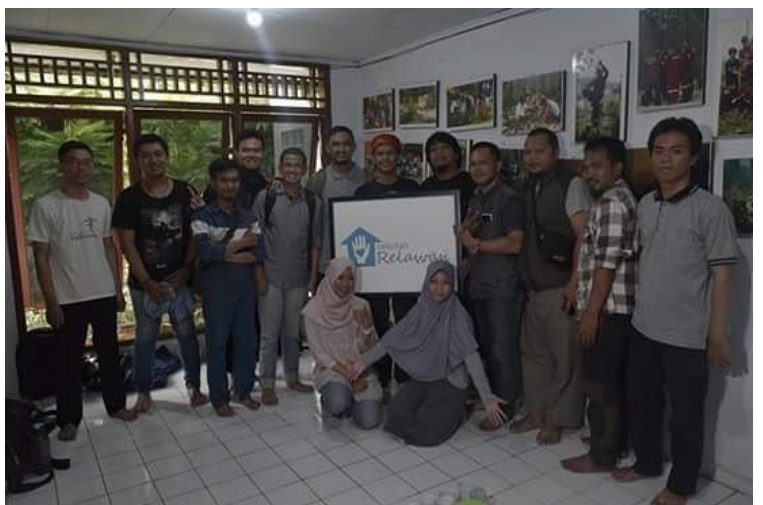

Gambar 1. Kegiatan Orientasi Relawan 2016 (Sumber: Instagram Official Sekolah Relawan)

Program selanjutnya adalah program yang berbentuk pelatihan (training). Sesuai dengan fokus yang dipilih lembaga, pelatihan dibuat mencakup isu sosial kemanusiaan, kebencanaan dan pengembangan masyarakat. Pelatihan isu sosial kemanusiaan bernama Volunteer Management Training (VMT). Lalu, pelatihan isu kebencanaan terbagi dua, yaitu Emergency Situation Training (EST) dan Disaster Leadership Training (DLT). Terakhir, di isu pengembangan masyarakat terdapat program pelatihan bernama ComDev Facilitator Training (CFT). Bentuk program pelatihan edukasi kerelawanan Sekolah Relawan berbeda dengan kegiatan atau event pada aspek durasi pelaksanaan. Program pelatihan edukasi berlangsung minimal dua hari dan maksimal empat hari. Selain pada waktu, perbedaan juga terdapat di aspek tempat, yang mana event hanya dilakukan di basecamp Sekolah Relawan atau ruang publik yang sederhana, sementara pelatihan biasanya di hotel atau villa tertentu. Hal ini bertujuan agar relawan lebih fokus untuk belajar dan juga ketika menginap peserta dapat membangun keakraban dengan relawan lainnya yang mungkin berbeda latar belakang.

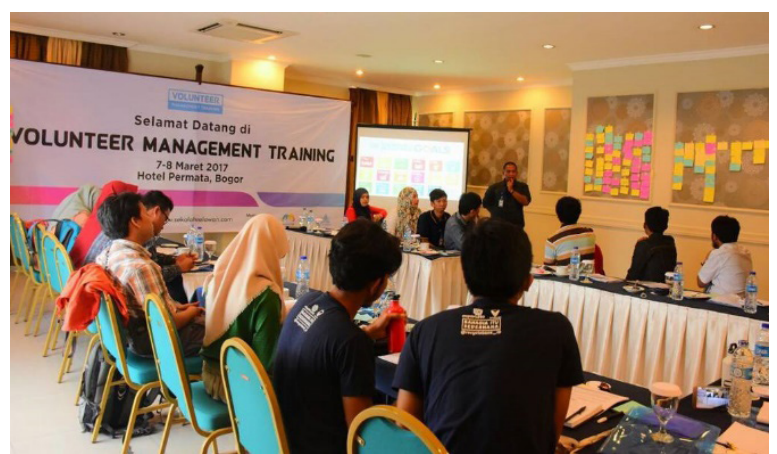

Gambar 2. Volunteer Management Training (Sumber : Dokumentasi Tim Keatif Sekolah Relawan)

Pada program pelatihan, peserta didik atau relawan pemula mendapatkan materi dari para pelatih atau trainer dan modul serta toolkits untuk dipakai lembaga atau komunitasnya. Sama dengan pelatihan pada umumnya, peserta berhak mendapatkan sertifikat dan juga relasi serta konsultasi dengan para mentor atau trainer yang berpengalaman dalam bidangnya. Pendekatan yang digunakan dalam program pelatihan adalah pendekatan partisipatif, dilakukan berkelompok, banyak bergerak dan trainer juga lebih banyak bertanya serta membuat simulasi sehingga peserta aktif dalam berargumentasi dan membuat banyak hal bersama. Jam di luar kelas pun menjadi waktu menarik tersendiri. Banyak hal yang dapat dilakukan oleh mereka seperti berkenalan dan tidak sedikit yang kemudian di antara para peserta ini melakukan sinergi dalam melakukan aksi-aksi kemanusiaan.

Kegiatan pelatihan yang dilakukan Sekolah Relawan sering kali bekerjasama dengan instansi pemerintah atau perusahaan; tidak hanya terbuka untuk umum, tetapi terkadang bisa juga tertutup atau dibuat sesuai dengan kebutuhan pihak yang ingin belajar. Misal, Sekolah Relawan pernah melakukan program Disaster Leadership Training (DLT) dengan tim dari PT. Hutama Karya (HK) untuk melatih tim mereka dalam keadaan situasi bencana di medan pembangunan atau konstruksi bangunan. Selain itu, masih ada beberapa instansi lainnya, baik di pemerintahan maupun perusahaan. Sinergi seperti ini juga menarik untuk memperluas pengetahuan tentang kerelawanan pada perusahaan dan aktor negara, sekaligus ajang promosi 
Sekolah Relawan agar dapat berkolaborasi untuk agenda aksi-aksi di lapangan. Menurut Shachar dan Hustinx (2019), umumnya perusahaan memiliki program dana Corporate Social Responsibility (CSR) dan semakin gemar membumikan programnya dengan strategi bertajuk kerelawanan. Sedangkan dengan pemerintah, Jakimow (2018) berpendapat bahwa menjadi relawan juga berpeluang memberikan kritik atas praktik kenegaraan. Relawan mempunyai legitimasi yang kuat dengan mengabdi kepada rakyat dan aktor negara pun demikian, hanya saja aktor negara digaji oleh pajak.

Bentuk yang terakhir adalah program edukasi kerelawanan berbentuk akademi. Program akademi ini menempuh waktu lebih panjang hingga satu tahun dan lebih sistematis serta terencana dalam pembelajaran materi kerelawanan. Program yang diinisiasi bernama Akademi Komunitas Nusantara (AKN). Program akademi ini sudah berjalan sejak tahun 2017 dan hingga sekarang sudah mencapai batch yang keempat.

Selama satu tahun peserta didik mempelajari materi kerelawanan melalui enam mata kuliah seperti, disaster management, sociopreneur, community leadership, community development, design thinking, dan volunteerism. Para pengajar yang mengampu mata kuliah tersebut adalah mereka yang telah berpengalaman dan memiliki pengetahuan minimal 10 tahun di bidangnya. Mereka telah memiliki pendidikan dan karya yang terbukti dan juga bersinergi sebagai education partner bersama AKN.

Seiring berjalannya waktu, AKN mengalami banyak perkembangan pada konten dan juga pengajar setiap tahunnya. Secara konsep, akademi ini dibuat layaknya kampus bagi para pegiat komunitas yang ingin belajar lebih dalam mengenai kerelawanan untuk pengembangan masyarakat. Pembelajaran hanya dilakukan di hari Sabtu pada pukul 10.00-12.00 WIB dan 13.00-15.00 WIB. Pembelajaran dijadwalkan di akhir pekan karena berbentuk pendidikan alternatif, sehingga jadwal dibuat berbeda dengan pendidikan formal. Selain itu, para peserta didik umumnya adalah mereka yang sudah matang secara pengalaman. Kalangannya cukup variatif, mulai dari yang sudah bekerja, masih sekolah menengah atas, hingga sudah berumah tangga. Dengan menanamkan filosofi pendidikan "sekolah ini tidak kasih anda ijazah, ijazah anda biar masyarakat yang kasih", membuat AKN tidak berfokus untuk memberikan gelar ataupun ijazah kepada peserta yang hadir. Hal ini menempatkan AKN sebagai akademi khusus orang-orang yang serius ingin belajar demi ilmu dan kebermanfaatan di masyarakat, sehingga berimplikasi pada variasi peserta yang sebelumnya disebutkan. Di antara para peserta banyak yang sudah lulus sebagai sarjana dari kampus ternama Indonesia, dan tak sedikit pula bergelar magister baik dari kampus dalam maupun luar negeri.

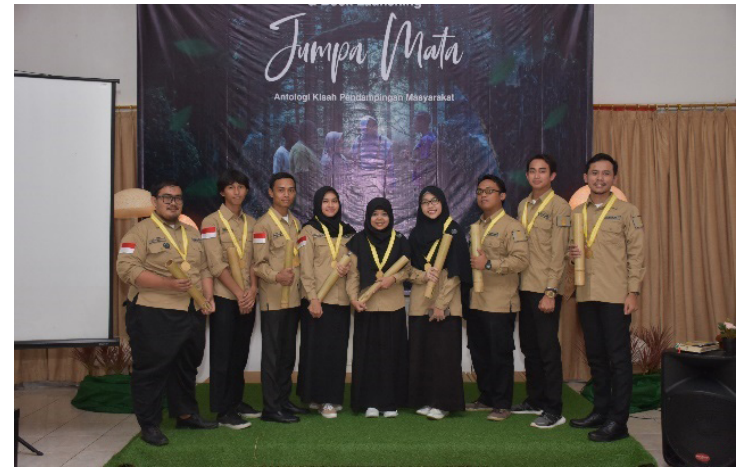

Gambar 3. $3^{\text {rd }}$ Annual Graduation AKN (Sumber : Instagram Official Sekolah Relawan)

Setiap akhir tahun pembelajaran, para peserta menampilkan sebuah karya yang telah digarap bersama oleh setiap angkatan sebagai bentuk perwujudan nilai yang telah sama-sama dipahami. Hal ini menjadi unik karena berbeda dengan pembelajaran pada umumnya. Mereka menampilkan karyanya dalam sebuah ritual khusus tahunan yang dinamakan " $A n$ nual Graduation”. Berbeda-beda di setiap tahunnya, $1^{\text {st }}$ annual graduation menyajikan cerita pembelajaran dengan sebuah konferensi yang mengundang komunitas se-Jabodetabek; lalu, pada $2^{\text {nd }}$ annual graduation para peserta membuat teater berjudul "Wardiman" di bawah kolong jembatan, bantaran kali Ciliwung, Depok; dan terakhir di $3^{\text {rd }}$ annual graduation para peserta menerbitkan buku dan mengadakan launching sekaligus bedah buku 
dalam acara penutupan. Angkatan sekarang (angkatan keempat) masih menimba ilmu dan direncanakan baru melaksanakan ritual tahunan pada pertengahan tahun 2021. Karya bersama dari para peserta AKN ini berpeluang menciptakan pembelajaran baru bagi masyarakat luas yang tidak memiliki keterikatan dengan orientasi formal dan bekerja untuk kebaikan bersama (Rozakou, 2016).

Kedua bentuk terakhir, baik pelatihan maupun akademi dilakukan secara berbayar. Mereka yang ingin belajar tetapi terkendala ekonomi tetap dapat mengikuti program tersebut berkat sistem subsidi silang dan afirmasi yang ditawarkan oleh Sekolah Relawan. Program akademi dan pelatihan secara berbayar mendorong antusias yang diperlihatkan oleh para peserta didik dalam pembelajaran. Seperti halnya Putra peserta AKN batch 3 yang mengatakan saat diskusi :

"Saya sangat berusaha semaksimal mungkin Kak untuk belajar, sayang juga sudah jauh-jauh, luangin waktu libur kerja, dan bayar masa tidak fokus." (Wawancara dengan Putra, 5 September 2020)

Dana belajar yang masuk digunakan oleh lembaga untuk membiayai operasional kegiatan, pelatihan serta akademi. Selain itu, dana juga dialokasikan untuk operasional berjalannya lembaga secara keseluruhan dan pengembangan pada edukasi dan aksi yang dilakukan oleh para pengelola.

Kemudian, Sekolah Relawan juga memiliki program pendampingan dalam menulis sebagai refleksi dan bahan pembelajaran bagi para relawan. Hasil tulisan tersebut dapat ditampilkan di media sosial, website atau dibukukan. Beberapa buku yang sudah diterbitkan menceritakan tentang aktivitas kerelawanan di lapangan, di antaranya buku berjudul "Positif Sinting: Petualangan Muda Mencintai Indonesia" dan buku "Sakayaku Kembali". Positif Sinting menceritakan pendampingan masyarakat di daerah pelosok oleh para anak muda dalam program bertajuk Tatar Nusantara, sedangkan Sakayaku Kembali merupakan buku kumpulan narasi bangkit dari para nelayan Donggala, Palu yang sebelumnya tertimpa bencana gempa tsunami. Buku pendampingan kebencanaan seperti ini membantu proses relawan mempelajari realitas bencana dalam momen kritis antara manusia dengan sesamanya beserta alam dan lingkungannya (Sabir, 2016). Buku-buku tersebut dijual bebas kepada umum melalui media sosial (digital marketing), atau pada kegiatan lembaga, komunitas, dan bundling di momen tertentu. Hasil penjualan buku juga digunakan untuk menunjang kebutuhan operasional lembaga (gambar 4).

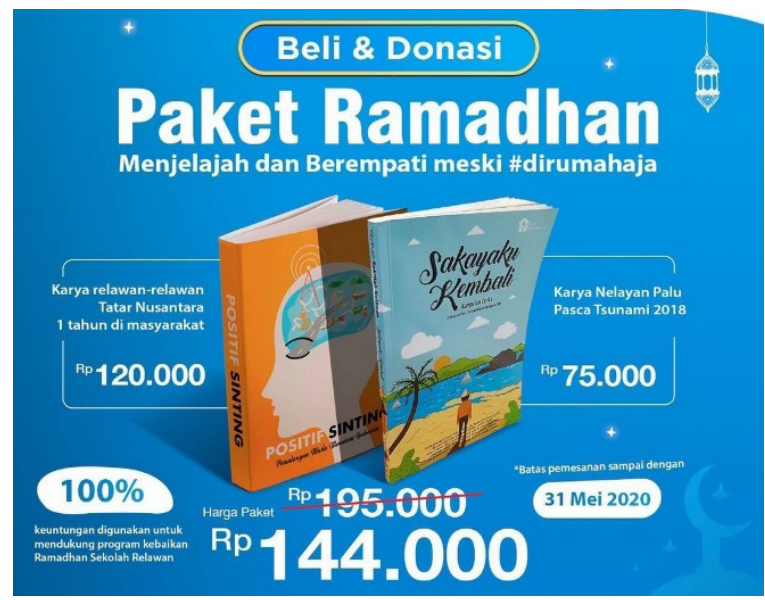

Gambar 4. flyer pemasaran buku Sekolah Relawan (Sumber : Instagram Sekolah Relawan)

Sekolah Relawan telah memulai program-program ini secara online, seperti Orientasi Relawan atau event lainnya menggunakan platform Zoom dan YouTube. Memang ada kelebihan dan kekurangan antara edukasi berbasis online dengan edukasi secara tatap muka langsung. Kekurangannya mengacu pada bonding yang tidak maksimal karena hanya bisa berkenalan lewat online. Lalu, terbatasnya percakapan karena tidak seperti saat offline yang bisa santai meneruskan pembicaraan sembari minum kopi atau makan bersama. Namun, hal ini dianggap lembaga sebagai langkah efisien menjangkau relawan lebih banyak dan mengikuti perkembangan zaman. Selanjutnya, sudah direncanakan teknologi edukasi melalui platform lain seperti podcast dan aplikasi Sekolah Relawan untuk para relawan.

\section{Kepercayaan Relawan Bersama Lembaga}

Struktur kepercayaan tercermin dalam strate- 
gi Sekolah Relawan mengikat para relawan terkait secara sosial yang dilakukan dengan menguatkan hubungan mutualisme antara lembaga dengan relawan. Seperti yang telah disampaikan oleh Mauss dalam The Gift (1954), bahwasanya tidak ada sesuatu yang cuma-cuma karena setiap hal memiliki fungsi sosial dan bernilai di dalam proses pertukaran.

Hal ini mungkin dilakukan juga oleh banyak pihak atau lembaga, termasuk negara yang melakukannya dengan banyak retorika (seperti: mencerdaskan kehidupan anak bangsa). Sekolah Relawan memberikan beasiswa atau fasilitas bantuan bagi mereka yang ingin belajar ilmu kerelawanan lebih jauh bersamanya. Tentu ada beberapa hal yang menjadi syarat untuk mendapatkannya, termasuk dikhususkan bagi mereka yang terkendala ekonomi. Hal ini sejalan dengan gagasan para pendahulu mengenai pendidikan bangsa Indonesia, yang mana semua warga negara memiliki hak untuk dapat mengenyam pendidikan. Terlebih bagi mereka yang sebelumnya aktif di Sekolah Relawan dalam banyak kegiatan dan mayoritas diisi oleh anak muda. Sangat menarik untuk bisa mengedukasi generasi muda supaya dapat memahami peran penting hubungan relawan dengan penerima manfaat, sehingga bisa membedakan pula perubahan atas dasar kepentingan proyek atau masyarakat yang sering kali terjadi hadir dalam proses pembangunan (Brown dan Green, 2015).

Beasiswa untuk belajar ini memiliki beragam pemetik manfaatnya. Salah satu yang peneliti coba temui untuk diskusi adalah Yanti Abdul Wahab (26 tahun) yang akrab dipanggil Kakak Yanti. Dia seorang relawan asal Flores Timur, tepatnya di Desa Lamahala, Pulau Adonara. Sebelumnya, Yanti adalah relawan di daerahnya dan bersama kerabatnya membantu merawat program-program di sana. Yanti mendapatkan informasi dari kerabatnya untuk belajar langsung di Akademi Komunitas Nusantara (AKN). Walaupun sudah sempat lulus sarjana di salah satu universitas, dia sangat antusias untuk dapat belajar dan berkegiatan sosial kemanusiaan. Sehari-hari Yanti dibiayai oleh kerabatnya di Jakarta dan ting- gal di AKN. Setelah lulus pun dia tidak langsung bekerja untuk memperoleh penghasilan, tetapi dia justru melanjutkan kegiatan kerelawanan yang terkadang kurang dihargai dan diperhatikan oleh masyarakat industri. Hanya berselang beberapa bulan, Yanti mendapatkan pekerjaan berpenghasilan berkat jejaring lembaga. Yanti mungkin hanya salah satu, karena masih banyak lagi relawan di luar Jabodetabek yang juga dapat menikmati program edukasi Sekolah Relawan.

Selain belajar dengan Sekolah Relawan, mereka pun sering kali diberikan kesempatan untuk aktualisasi diri pada program di daerah pedesaan, pedalaman atau lokasi bencana. Relawan yang mayoritas masih berusia muda, umumnya mereka sangat antusias karena bisa mendapatkan pengalaman baru. Banyak cerita menarik seperti pertama kali naik pesawat, perdana tinggal di daerah yang belum teraliri listrik dan air dari pemerintah, sulit berkomunikasi dengan keluarga karena kehilangan sinyal dan masih banyak lagi. Mereka mendapatkan banyak relasi baru dengan multi stakeholder mulai dari akademisi, masyarakat setempat, pemerintahan, dan media yang kemudian juga menjadi bahan pembelajaran secara tidak langsung. Kegiatan mereka di lapangan pada akhirnya berbuah refleksi ketika pulang. Bukan hanya evaluasi dan bercerita tentang apa yang dilakukan, mereka juga mengembangkan kreativitas dan menghasilkan karya. Bentuk karya yang disajikan beragam dan menarik, seperti dengan buku antologi, video dokumenter, teater seni dan lainnya.

Pengalaman lain menjadi seorang relawan juga didapat oleh Ali (21 tahun), seorang relawan yang berasal dari Sukabumi. Ali yang awalnya belum mengetahui kegiatan kerelawanan, sekarang telah mampu berbagi pengalamannya saat kegiatan edukasi berlangsung. Dia mencoba menerapkan ilmu yang dimiliki melalui aksi-aksi kerelawanan di kampung halamannya. Sebelumnya, Ali mendapatkan informasi untuk bisa aktif belajar dan berkegiatan dari temannya yang juga relawan Sekolah Relawan. Temannya tersebut bernama Dodi yang jauh lebih lama bergabung dan merintis 
komunitas bernama Ruang Peduli, Sukabumi. Ali mengikuti rangkaian edukasi kerelawanan secara bertahap mulai dari orientasi, lalu pelatihan kebencanaan, dan terakhir belajar tentang pengembangan masyarakat. Ali kurang lebih sudah dua tahun bersama Sekolah Relawan mendapatkan edukasi, mentoring, dan juga pengalaman berharga ke beberapa lokasi bencana alam. Hal ini membentuk loyalitas yang menjadikannya sangat komunikatif di grup relawan apabila ada panggilan tugas kemanusiaan dari lembaga; termasuk kepekaan pada masalah sosial yang ada di lingkungan tempat tinggalnya. Selama proses tumbuh belajar bersama lembaga, dia terus memahami nilai-nilai dan harapan besar lembaga beserta upaya bersama seluruh relawan tergabung.

Penghargaan juga diberikan oleh seluruh pihak yang terkait dengan lembaga kepada para relawan atas kontribusinya dalam aktivitas edukasi maupun aksi. Tidak hanya oleh pendiri dan internal yang mengelola lembaga, tetapi juga oleh masyarakat dan sesama relawan yang tergabung. Apresiasi yang diberikan cukup sederhana, dimulai dengan pelukan, ucapan terima kasih, sajian makan malam bersama dengan teman-teman yang lain, dan kesempatan untuk saling mendengarkan cerita. Selain itu, Sekolah Relawan juga memudahkan para relawannya apabila membutuhkan surat rekomendasi untuk kebutuhan lainnya atau sertifikat yang juga menunjang bagi relawannya. Setiap bulan atau tahun, Sekolah Relawan membuat ritual bagi relawan terbaiknya. Ritual berwujud pemberian hadiah uang saku, pemberian barang-barang yang memang dibutuhkan semisal APD untuk aksi bencana, buku, tas dan sepatu lapangan, hingga umroh ke tanah suci. Hal ini bertujuan untuk memberikan motivasi, yang mana tingginya motivasi akan memengaruhi kemauan yang tinggi pula dalam proses belajar (Widyastuti, Ambarsari, Jannah, Anggoro, dan Rustini, 2021).

Pemberian yang dilakukan oleh lembaga selalu punya mekanisme khusus yang memberikan efek kejut bagi siapapun yang menerimanya. Peneliti juga mengamati bahwa apresiasi ini bukan menjadi sesuatu yang dikejar oleh para relawan, sehingga tidak banyak kompetisi layaknya dalam korporasi atau instansi yang justru berdampak buruk dalam kerja-kerja keseharian, khususnya dalam aspek kemanusiaan. Menurut Maess (2012), motivasi relawan yang menjunjung tinggi nilai sosial terkadang sering juga dieksploitasi oleh pihak tertentu. Ruang aktualisasi diri jauh lebih penting dan menjadi wacana yang terus disosialisasikan bagi para relawan sehingga tidak ada relawan terbaik, melainkan hanya ada relawan terlatih. Hal ini menjadi sebuah pesan penting yang membekas dari para pendiri.

Selain itu, ruang media sosial juga menjadi hal yang tidak kalah penting. Para relawan sering diajak berdiskusi dan diminta kesediaannya untuk bercerita mengisi konten media Sekolah Relawan; baik dalam bentuk video, flyer ataupun tulisan. Tim kreatif lembaga memberikan sentuhan estetis untuk mengemas dan menyajikannya ke para pengikut di media sosial. Di dalamnya, testimoni menjadi sebuah artefak yang bernilai untuk dapat dinikmati banyak pihak, dan memiliki korelasi dengan pertumbuhan banyak pihak yang ingin bergabung, baik dari pemerintahan, donatur publik dan tentu insan muda lainnya agar tergerak kemauannya menjadi relawan.

Sekolah Relawan juga kerap memberikan bonus berupa produk-produk atau merchandise untuk para relawan yang berkegiatan. Produk tersebut di antaranya kaos, kemeja lapangan, botol tumblr, buku dan lain-lain. Apa yang mereka gunakan pun sebenarnya memiliki nilai simbolis, berupa brand lembaga yang secara tidak langsung diaktivasi oleh mobilisasi para relawan. Tidak sedikit dari mereka yang dengan bangga mengabadikannya dan mengunggah di media sosial masing-masing. Mereka menceritakan kegiatannya bersama Sekolah Relawan dengan gaya masing-masing yang pasti menarik apabila dikaji lebih serius dalam perspektif media kreatif.

Vidal (2014) menyatakan bahwa pemberian hadiah tersebut pada hakikatnya tidak akan terjadi secara otomatis. Beberapa poin yang dilakukan sebagai sebuah pemberian ber- 
dampak sangat baik dalam proses tumbuh lembaga. Mereka yang mendapatkan fasilitas belajar dan berkegiatan bersama Sekolah Relawan sering kali tidak perhitungan terkait masalah ruang dan waktu. Kesigapan pun terbentuk ketika ada kebutuhan relawan untuk membantu saudara kita yang tertimpa bencana. Mereka seakan memiliki alarm khusus untuk dapat melihat banyak gejala sosial dan berusaha menjadi generasi yang membawa perubahan baik dalam lingkungan sendiri ataupun kehidupan sebuah keluarga. Mereka telah memahami program yang dimiliki Sekolah Relawan dan paham bagaimana cara menggali infomasi serta hal yang dibutuhkan dalam lembaga. Secara tidak langsung relawan di sini menjadi perpanjangan tangan kebaikan bagi lembaga di daerah masing-masing. Loyalitas antara relawan dan lembaga menjadi penting. Modal sosial yang terus dirawat dan dikembangkan, meneguhkan asumsi dasar pendiri bahwa edukasi kerelawanan menjadi signifikan untuk aktivitas kerelawanan agar tumbuh jauh lebih berkualitas.

\section{Asumsi Dasar Sebagai Pedoman Edukasi Kerelawanan}

Setiap organisasi ataupun lembaga tentu memiliki tujuan atau cita-cita yang diharapkan. Hal tersebut dapat diwujudkan baik dalam bentuk yang tercatat atau tidak tercatat, dan dapat disusun secara sitematis atau tidak sistematis. Begitu juga dengan Sekolah Relawan sebagai lembaga sosial kemanusiaan memiliki mimpi besar di bidang edukasi kerelawanan.

Asumsi dasar pendiri Sekolah Relawan membawa mimpi besar itu yang dituangkan dan diturunkan sebagai pedoman semua anggota pengelolanya dalam mencapai target. Hal ini tampak dalam pernyataan pendirinya:

"Sekolah Relawan memiliki mimpi besar di tahun 2030 menjadi sebuah pusat edukasi kerelawanan dalam skala internasional. Kita ingin bisa memfasilitasi relawan bukan hanya yang ada di Indonesia, namun juga lintas budaya, lintas negara." (Wawancara dengan Bayu Gawtama, pendiri Sekolah Relawan, 13 September 2020)

Ucapan Bayu Gawtama menggambarkan visinya sebagai pendiri. Ia membuat anak tangga bagi timnya untuk mencapai visi itu secara logis. Pendiri Sekolah Relawan menyatakan bahwa kepercayaan yang telah terbangun kuat di segenap pengelola meneguhkan niat dengan menanamkan keyakinan dan juga membangun pondasi yang kuat bagi lembaga yang ia dirikan. Bagi pendiri, kerja-kerja luar biasa yang telah ia lakukan bersama tim menjadi sebuah bentuk kolaborasi yang selalu ingin dicapai.

Pendiri Sekolah Relawan membagi 6 tahap atau fase yang disusun dengan keterangan waktu serta nomenklatur unik untuk mengedukasi para relawan. Tahapan tersebut adalah:

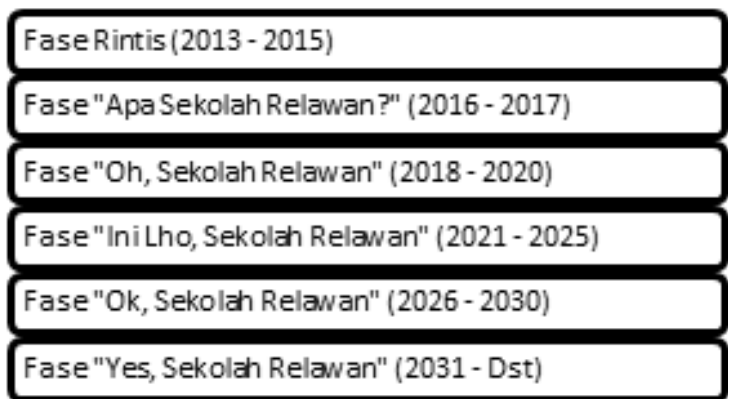

\section{Bagan 1. Bagan tahapan perkembangan Sekolah Relawan}

Pada beberapa tahapan ini, setidaknya peneliti menganalisis ada empat upaya pengembangan yang ingin dicapai organisasi di antaranya: 1) pengembangan infrastruktur, 2) manajemen, 3) jejaring dan 4) unit usaha.

Empat upaya tersebut direncanakan dan saling terhubung satu sama lain. Di dalam pengembangan infrastruktur, lembaga mencoba mengembangkan bangunan mereka mulai dari silabus, kurikulum, alur pembelajaran dan seterusnya. Agar dapat dikonsumsi oleh relawan lintas negara, materi-materi tersebut memungkinkan disajikan dengan bahasa internasional. Di samping itu, Sekolah Relawan juga mencoba membangun infrastruktur pembelajaran dengan memberikan fasilitas bagi relawan untuk singgah dan menginap selama 
masa pendidikan. Sejauh penemuan ide yang coba diutarakan oleh pendiri ialah memiliki graha relawan yang di dalamnya tersedia ruangan yang beragam untuk kepentingan edukasi relawan.

Aspek lain yang tidak kalah pentingnya adalah pengembangan sumber daya manusia beserta manajemen pengelolaan. Profesionalitas juga dibangun dengan meningkatkan jenjang pendidikan, memberikan pelatihan dan sertifikasi bagi para pengajar. Hal ini sudah dimulai oleh beberapa pengelola dalam tim Sekolah Relawan yang melakukan studi banding ke lembaga dalam negeri dan luar negeri. Selain itu, legalitas dan audit untuk menunjang manajemen yang terpercaya juga terus ditempuh di level yang lebih tinggi.

Pengembangan lain yang direncanakan oleh pendiri dan tim manajemen dalam road map lembaga ialah target pencapaian dan pengelolaan jejaring. Mereka meyakini jejaring yang dikelola dengan baik akan berdampak signifikan terhadap pertumbuhan lembaga. Hal ini diperkuat dengan beberapa pengalaman lembaga dari pertama berdiri hingga saat ini. Jejaring yang dirawat bersifat multi sektor dari jaringan bersama aktor negara, pengusaha, komunitas atau lembaga sejenis dan juga media regional hingga internasional.

Hal terakhir yang tidak kalah penting adalah perintisan usaha di luar lembaga oleh pendiri yang diharapkan menjadi bantuan sumber pendanaan bagi berjalannya aktivitas edukasi kerelawanan. Usaha ini merupakan bentuk kemandirian lembaga serta bagian dari bantuan fasilitas subsidi bagi para relawan yang ingin belajar, seperti yang telah dijelaskan sebelumnya.

Upaya pengembangan yang telah ditentukan senantiasa disosialisasikan dengan cara yang beragam oleh para pendiri bersama lembaganya. Hal ini dilakukan agar semua relawan maupun pengelola lembaga menjadikannya mimpi bersama, sehingga dapat diupayakan bersama pula.

Semua bagian dari lembaga pun meyakini bahwa karakter yang kuat bisa menjadi modal awal dan penting bagi diri seorang relawan. Lembaga yang cukup banyak terpengaruh pada nilai-nilai keislaman ini sering menyederhanakannya dengan, "relawan harus punya akhlak yang baik". Karakter ini sulit dikalkulasi, dan tidak tampak secara fisik. Namun, sesama relawan dapat merasakannya ketika hadir bersama dalam rangkaian pembelajaran baik di dalam ruangan maupun saat aksi di lapangan.

Beberapa karakter relawan yang diharapkan oleh Sekolah Relawan pun dituliskan dalam road map lembaga, di antaranya karakter personal yang baik, cerdas, terampil, tangguh dan sigap. Karakter-karakter tersebut akan melengkapi kompetensi yang dimiliki. Harapannya relawan di Indonesia tidak hanya banyak secara kuantitas, tetapi juga dapat berkualitas. Seperti pernyataan yang sering diutarakan oleh Bayu Gawtama selaku pendiri dalam setiap sesi edukasi bahwasanya tidak ada relawan yang hebat, tapi yang ada adalah relawan yang terlatih.

Edukasi kerelawanan yang terkonsep dengan baik diharapkan oleh para pengelola berdampak pada kesiapsiagaan menjadi relawan di lapangan dalam kondisi apapun dan bukan hanya bencana (Ambarika, 2016). Hal ini juga sebagai bukti dari indeks kedermawanan bangsa ini bersama para relawan di urutan terbaik secara internasional. Sejarah kedermawanan dan kerelawanan ini telah ada lama di Indonesia dan terus berkembang, termasuk di dalamnya mungkin Sekolah Relawan akan tercatat dengan baik sebagai pembelajaran kini serta masa depan.

\section{Simpulan}

Upaya edukasi relawan yang dilakukan oleh Sekolah Relawan bisa sangat terlihat dari model edukasi yang dikembangkan, baik berupa program edukasi jangka pendek maupun jangka panjang. Hal ini juga senada dengan asumsi dasar pendiri organisasi bahwasanya tidak cukup bermodalkan niat untuk bisa menolong orang lain, tetapi juga butuh ilmu. Apabila itu tidak terjadi, kegiatan kerelawanan juga 
bisa menimbulkan bahaya bagi diri relawan maupun individu yang hendak dibantu. Oleh karena itu, ada pembelajaran dan nilai-nilai yang perlu tumbuh dari setiap relawan melalui edukasi dengan beberapa artefak yang digunakan untuk mendukung peningkatan kapasitas dan kompetensi relawan.

Selain itu, langkah untuk saling kolaborasi juga merupakan hal penting dalam membentuk kepercayaan. Kolaborasi yang beragam antara teori - praktik, pengajar - peserta belajar, manajemen edukasi - fasilitas edukasi, dan juga keterlibatan multi-stakeholder yang terdiri dari pemerintah dan jejaring komunitas relawan yang memiliki kesamaan visi. Terakhir, saling memberi hadiah juga dilakukan sebagai sebuah kepercayaan untuk dapat meningkatkan loyalitas antara relawan yang terlibat dengan Sekolah Relawan.

\section{Daftar Pustaka}

Ambarika, R. (2016). Efektivitas Edukasi dan Simulasi Manajemen Bencana Terhadap Kesiapsiagaan Menjadi Relawan Bencana. Jurnal Kesehatan Mesencephalon, 2(4), 245-250.

Banerjea, N. (2011). Voluntary Participation and Self-Governance: A Study of Community Health Volunteering in Kolkata, India. Cultural Dynamics, 23(3), 197-218.

Brown, H., dan Green, M. (2015). At the Service Community Development: The Professionalization of Volunteer Work in Kenya and Tanzania. African Studies Review, 58(2), 63-84.

Faas, A. J., dan Barrios, R. E. (2015). Applied Anthropology of Risk, Hazards, and Disasters. Human Organization, 74(4), 287-295.

Fathy, R. (2019). Modal Sosial: Konsep, Inklusivitas, dan Pemberdayaan Masyarakat. Jurnal Pemikiran Sosiologi, 6(1), 1-17.

Fisher, W. F. (1997). Doing Good? The Politics and Antipolitics of NGO Practices. Annual Review of Anthropology, 26(1), 439-464.

Graeber, D. (2002). Toward an Anthropological Theory of Value: The False Coin of Our Own Dreams. New York: Palgrave.

Haski-Leventhal, D., dan Bargal, D. (2008). The Volunteer Stages and Transitions Model: Organizational Socialization of Volunteers. Human Relations, 61(1), 67-102.

ILO: International Labour Office. (2011). Manual on the Measurement of Volunteer Work. Geneva: International Labour Office

Jakimow, T. (2018). Volunteer's Practices of Care in Community Development as a Model for Citizenship in Medan, Indonesia. Citizenship Studies, 22(2), 145-159.

Maess, K. (2012). Volunteerism or Labor Exploitation? Harnessing the Volunteer Spirit to Sustain AIDS Treatment Programs in Urban Ethiopia. Human Organization, 71(1), 54-64.

Maldonado, J. (2016). Considering Culture in Disaster Practice. Annals of Anthropological Practice, 40(1), 52-60.

Mauss, M. (1954). The Gift. London: Cohen dan West.

Rozakou, K. (2016). Crafting the Volunteer: Voluntary Associations and the Reformation of Sociality. Journal of Modern Greek Studies, 34(1), 79-102.

Sabir, A. (2016). Gambaran Umum Persepsi Masyarakat Terhadap Bencana di Indonesia. Jurnal Ilmu Ekonomi Dan Sosial, 5(3), 304-326.

Schein, E. H., dan Schein, P. (2017). Organizational Culture and Leadership (5th ed.). San Fransisco: John Wiley dan Sons.

Shachar, I. Y., dan Hustinx, L. (2019). Modalities of Agency in a Corporate Volunteering Program: Cultivating a Resource of Neoliberal Governmentality. Ethnography, 20(2), 205226.

Skidmore, R. A. (1983). Social Work Administration, Dynamic Management, and Human Relationship (3rd ed.). Boston: Allyn dan Bacon.

Syarif, A. M. (2018). Semua Suka Mengabdi. Bogor: TCA Publishing.

Utomo, M. H., dan Minza, W. M. (2016). Perilaku Menolong Relawan Spontan Bencana Alam. Gadjah Mada Journal of Psychology, 2(1), 48-59.

Vidal, D. (2014). The Three Graces, or the Allegory of the Gift : A Contribution to the History of an Idea in Anthropology. HAU: Journal of Ethnographic Theory, 4(2), 339-368.

Widyastuti, M., Ambarsari, N., Jannah, S. N., Anggoro, S. D., dan Rustini, S. A. (2021). Motivasi dan Pengetahuan Relawan Tentang Penanggulangan Bencana. Jurnal Ilmiah Keperawatan Stikes Hang Tuah Surabaya, 16(1), 1-6. 